\title{
Relationship Between Ethical Leadership, Organizational Commitment and Job Satisfaction at Hotel Organizations
}

\author{
Otel Işletmelerinde Etik Liderlik, Örgütsel Bağlıık ve Iş Tatmini Arasındaki İlişki
}

Sedat ÇELIK ${ }^{1}$, Bekir Bora DEDEOĞLU² , Ali INANIR³

\begin{abstract}
The main purpose of this study is to examine the relationship between ethical leadership style, organizational commitment and job satisfaction in hotel industries and to reveal the mediator role of organizational commitment between ethical leadership and job satisfaction. The study was carried out with 371 participants working in four star and five star hotels in Antalya. Following the research, it was found that ethical leadership has a positive effect on organizational commitment and job satisfaction and organizational commitment has a positive effect on job satisfaction. It was also found that organizational commitment has a partial mediator function between ethical leadership and job satisfaction.
\end{abstract}

Keywords: Ethical leadership, organizational commitment, job satisfaction, hotel organizations

\section{INTRODUCTION}

Many managers and researchers are aware that to effectively compete in the market, businesses need to retain their employees. Minimizing employee intention to leave is possible if employees feel committed to the business (Naqvi, 2011).

It is important for all kind of businesses to ensure organizational commitment and job satisfaction. Tourism, which is a labor-intensive service sector, has a high human relationship and values job satisfaction and organizational commitment more than other sectors (Toker, 2007). In accommodation businesses, having an important position in the tourism sector work schedule is notably tiring. Therefore, organizational commitment level is often low, intention to leave is excessive and employee turnover rates can be high (Su, Lee and Fan, 2011; Üngüren, Cengiz and Algür, 2009; Rızaoğlu and Ayyıldız, 2008).

Many factors can affect employee job satisfaction and their feelings regarding organizational commitment. However, one of the most important factors is the leadership behavior of managers (Webb 2011).
ÖZET

Yöneticiler otel işletmelerinde çalışanlarına karşı etik, adaletli ve dürüst davranarak çalışanları kendisine ve işletmeye bağıı kalmasını sağlayarak iş tatminini arttırmalıdırlar. Bu çalışmanın amacı otel işletmelerinde etik liderlik tarzının örgütsel bağlılık ve iş tatmini üzerindeki etkisini araştırmak ve örgütsel bağlıı̆̆ın etik liderlik ve iş tatmini arasındaki aracılık rolünü ortaya koymaktır. Çalışma Antalya'daki 4 ve 5 yıldızlı otel işletmelerinde çalışan 391 katılımcı ile gerçekleştirilmiştir. Elde edilen veriler LISREL programı ile analize tabi tutulmuştur. Araştırma sonucunda etik liderliği örgütsel bağlılık ve iş tatmini üzerinde ve örgütsel bağlılığın iş tatmini üzerinde olumlu etkisi olduğu ortaya çıkmıştır.

Anahtar Kelimeler: Etik liderlik, örgütsel bağılıı, iş tatmini, otel işletmeleri

Leaders can influence and lead (manage) their employees, but those who are not ethical, honest and reliable have difficulties in keeping their employees (Brown and Mitchell, 2010; Toor and Ofori, 2009; Ulrich, O'Donnell, Taylor, Farrar, Danis and Grady 2007). The studies of Viteel and Singhapakdi (2008) have shown that open (clear) ethical behavior on the part of managers positively affects job satisfaction and organizational commitment. Thus, employees could adhere to their managers and businesses with the help of managers' ethical behaviors and imposing that to their employees and the confidence occurred due to working in a fair environment (Schwepker, 2001; Deconinck, 2010).

While there has been research carried out on the relationship between ethical leadership, organizational commitment and job satisfaction, this relationship has not sufficiently been examined in terms of hotel businesses, as one of the most important stakeholders of the tourism sector. Therefore, (1) the relationship between ethical leadership, organizational commitment and job satisfaction in hotel industries and (2) the mediator role of organizational commit-

\footnotetext{
${ }^{1}$ Lecturer, Şırnak University, School of Tourism and Hospitality Management, Department of Travel Management, sedattcelik@gmail.com

${ }^{2}$ Res.Ass., Akdeniz University, Faculty of Business, Department of Tourism Management, bbdedeoglu@akdeniz.edu.tr

${ }^{3}$ Lecturer, Mehmet Akif Ersoy University, Ağlasun Vocational Higher School, Department of Cultural Heritage and Tourism, ainanir@mehmetakif.edu.tr
} 
ment between ethical leadership and job satisfaction were examined in this study. In this regard, the study is important in terms of contributing to the literature and raising the awareness of employees working in the tourism sector. It is also hoped that the findings will inform employees and management about ethical leadership, organizational commitment and job satisfaction. Within this scope, a questionnaire study was conducted and the findings were tested using the LISREL programme.

\section{LITERATURE REVIEW}

\subsection{Ethical Leadership}

Today, the term 'ethics' commonly refers to a written or unwritten ethical system that defines what is culturally considered wrong or right, good or bad (Aronson, 2001) and what kinds of components an ethical and virtuous lifestyle contains (April, Locke and Mlambo, 2010). On the other hand, within the field of leadership, researchers have not yet found a common definition for what constitutes ethics. Leadership defined by Davis (1981: 141) as "the capability of convincing people to strive in order to reach the organizational goals". After examining many definitions, Çelik (2012: 6) defined leadership as "a process during which the goals of a business or a group are determined and the group members are led to reach these goals with the help of influence."

In many studies conducted on leadership, the emphasis has been on the leadership process, leader behaviors, relationship with audience and organizational outputs (Gardner et al., 2005; April et al., 2010; Aianei, 2006; Powers, 2006; Adeyemi, 2010; Yukl, 2002). However, in recent years, leadership has become associated with current unethical behaviors (see, for example, Enron, WorldCom, Parmalat) in business life, and governments have imposed new regulations enhancing studies in ethical leadership (Brown, Trevino and Harrison, 2005; Resick et al. 2011; Den Hartog and Belschak, 2012). Since the 2000s, many studies (Aronson, 2001; Van den Akker, Heres, Lasthuizen and Six, 2009; April et al., 2010; Mihelic, Lipicnik and Tkavcic, 2010; Kalshoven, Den Hartog, De Hoog, 2011; Elçi, Şener, Aksoy and Alpkan, 2012) have focused on what ethical leadership behavior should be and what its effects are. Resick et al. (2011) stated that most leadership theories and research were created with a Western perspective in mind. However, as they write, ethical leadership studies have also been discussed from a Chinese perspective and have been inspired from Confucian philosophy, adding that most ethical leadership research were examined by paternal leadership researchers.
Aronson (2001) was one of the first researchers who studied ethical perspectives and leadership styles together (Acar et al., 2012; Zhu et al., 2004). Additionally, Brown et al. (2005) were among first researchers to empirically study ethical leadership. According to Brown et al. (2005: 120), ethical leadership is "the demonstration of normatively appropriate conduct through personal actions and interpersonal relationships, and the promotion of such conduct to followers through two-way communication, reinforcement, and decision-making". Zhu, May and Avolio (2004: 18) defined ethical leaders as "individuals who are impartial and unbiased, exhibit ethical behaviors, take the wishes of people into notice and protect their employees' rights fairly". Ethical leaders guide not only their workers in their enterprises but also the shareholders and aims of the enterprise (Elçi et al., 2012) and they are role models for their followers (Watson, 2010). Resick et al. (2006), in their study, indicated that 6 common characteristics of ethical leaders are character and honesty, ethical awareness, focusing on society, ability to motivate, encourage, empower and take ethical responsibility.

In Bass's (1990) transformational leadership theory, the idealized influence dimension puts forward the ethical aspect of leadership. However, Brown et al. (2005) emphasized that the idealized influence dimension reflects visionary leadership and is not related with ethical leadership. Additionally, Bass and Steidlmeier (1999) stated that transformational leadership should be examined equally with ethical leadership. They distinguished between authentic and false transformational leadership. False transformational leadership refers to a leader who is dishonest and unreliable and only thinks of his/herself, whereas authentic transformational leadership refers to leaders who care about other people and pay attention to constitution-based values of individuals who have adopted ethical values. Trevino, Brown and Hartman (2003) stated that the primary purpose of ethical leadership is to standardize behaviors and to set ethical values and principles, as these elements affect performance in a positive way. The European Business Ethic Commission indicated that 13 steps should be followed in order to create an ethical culture and emphasized that leaders should practice ethical principles and 'walk the talk' (Dercks, 2001).

Since leaders have the power and ability to lead and influence people, they influence mood (morale), motivation, performance and behaviors of employees. Therefore, leaders should behave ethically and express themselves clearly in order that employees in turn act in an ethical way (Brown and Mitchell, 2010; 
Den Hartog and Belschak, 2012; Thomas, Schermerhorn and Dienhart, 2004). The reason why top managers are successful is that they understood the ethical concepts and behave in accordance with them. To improve ethical behaviors continuously and to work more ethically each day, managers need to willing (Thomas et al., 2004). Additionally, ethical leadership is an important component in terms of creating an ethical organizational culture and environment (Trevino et al., 2003). Besides, improvement observed in ethical leadership behaviors positively affects the commitment, organizational confidence and interpersonal relationships of employees (Ahmed et al., 2012; Brown et al., 2005).

\subsection{Job Satisfaction}

Research on job satisfaction started in the 1930s and has since then been the most focused subject of organizational behavior (Kim, Tavitiyaman and Kim, 2009). Researchers (Locke, 1976; Hoppock; 1935) have defined job satisfaction in different ways. One of the first definitions of the concept was by Hoppock (Tsai et al., 2007) who stated that psychological, physical and environmental conditions are affective on employees who say, "I am pleased with my job" (Yew, 2008: 30). One of the most comprehensive and acceptable definitions of job satisfaction in the literature is by Locke. Locke (1976) stated that job satisfaction is a positive emotion occurring as a result of employee value regarding job and working environment and perceptional interaction and is a result of employees' assessments regarding their expectations from the job and real working environment. When the definitions are examined, it can be stated that job satisfaction is the contentment employees gain from their jobs.

Job satisfaction has also been expressed as an important component in many theories (Two Factor Theory, Equity Theory, and Maslow's Theory of Hierarchy of Needs, etc.) (Aziri, 2011; Toker, 2007). As well, much job-satisfaction based research has been carried out (Üngüren et al., 2009; Saari and Judge, 2004; Van Saane et al., 2003; Lam, 2001; Azıri, 2011) using end scales (the Minnesota satisfaction scale, job description scale, Porter Need and Satisfaction scale, etc.) that have been developed to measure job satisfaction. For instance, the Minnesota Job Satisfaction Scale, developed by Weiss (1967) and a preferred scale in the research literature, is composed of three dimensions: internal (value, responsibility, success, social statue, position in the job, etc.) and external (wage, promotion, employee relationships, supports, management policies and applications, etc.) employee relationships and total job satisfaction (total of internal and external satisfaction.). The Michigan
Organizational commitment Assessment SurveySub-Scale of Job Satisfaction is an another job satisfaction scale composed of three questions and commonly used in the research literature for examining job satisfaction in a general sense. The reason why job satisfaction is so intensively researched is that it is important for both businesses and employees. It is important for business, because it affects productivity, performance, profits and many other outputs. It is also important for employees because having a good working life meets the needs of employees and positively affects life quality (Üngüren et al., 2010).

\subsection{Organizational Commitment}

The importance of organizational commitment has been emphasized in the literature as it relates to many subjects (i.e., job, profession, career, business) in many areas (i.e., sociology, industrial psychology, health psychology) (Martin and Roodt, 2008). Although much research has been done, often using improper scales, organizational commitment can be difficult to synthesize and define (Meyer and Allen, 1991; Kimbel, 2002). In general, organizational commitment describes the affective commitment of employees to their business (Mathieu and Zajac, 1990; Naqvi et al., 2011). Porter, Crampon and Smith (1976: 87-98) define organizational commitment "as the relative strength of an individual's identification and involvement in a particular organization". Buchanan (1974: 533) defined organizational commitment as a "partisan, affective attachment to the goals and values of an organization, to one's role in relation to goals and values, and to organization for its own sake, apart from, it's purely instrumental worth."

The most focused models used to explain organizational commitment are the Three Dimensional Organizational Commitment Model of Meyer and Allen and the Organizational Commitment Model of Mowday and his associates. Meyer and Allen (1991) separated organizational commitment into three dimensions: affective commitment, continuance commitment and normative commitment. Affective commitment is defined as staying in a job for emotional reasons; continuation commitment, commitment caused by the fear of losing the gains (money, position, etc.) from a job; and normative commitment defines the commitment, which is based on the feeling that leaving a job would be unethical because of employee's responsibilities and obligations (Brown, 2003; Cohen, 2007). Mowday, Steers and Porter (1979) indicated that in order to insure organizational commitment, it is necessary to (a) accept the values and goals of a business; (b) to voluntarily make an effort for the interests of the business; and (c) to have 
a wish to stay in the business (Maxwell and Stelee, 2003). Similarly, Buchanan (1974) indicated that such factors as business identification, involvement and loyalty are necessary for organizational commitment. Mowday et al. (1979) examined organizational commitment in terms of attitudinal and behavioral aspects in their organizational commitment scale. The attitudinal perspective presents the identification of values and aims of employees with the enterprise's values and aims, whereas behavioral perspective defines commitment according to the employee's approach towards problems in enterprises and his/ her continuation in the enterprise (Meyer and Allen, 1991).

The one-dimensional organizational commitment scale of Mowday et al. (1979) was used in this study because it was preferred in many studies (Cohen, 1993; Testa, 2001; Suki and Suki 2011; Çokluk and Yılmaz, 2010; Çavuş and Gürdoğan, 2008) and it reveals the psychometric characteristics of employees in detail (Angle and Perry, 1981).

2.4. Ethical Leadership, Organizational Commitment and Job Satisfaction Relationships in the Hotel Industry

There are many studies (Ahmadi, Ahmadi and Zohrabi, 2012; Atmojo, 2012; Darvish and Rezaei, 2011; Munir et al., 2013; Ponnu and Tennakoon, 2009) in the literature that examine the relationship between organizational commitment and job satisfaction. However, the research, especially targeting the relationship of ethical leadership with organizational commitment and job satisfaction, is notably limited. It has been established that leaders are effective in creating organizational commitment and ensuring job satisfaction (Mathieu and Zajac, 1990; Lam, Zhang and Baum, 2001). The ethical behavior of leaders especially increases the commitment and job satisfaction of employees (Ahmed et al., 2012; Brown, 2005). Ghahroodi, Mohd and Ghorban (2013), Zhu et al. (2004), Lim (2012), Toor and Ofori (2009) found in their studies that ethical leadership positively affects organizational commitment, while ethical leadership may also have a positive effect on job satisfaction (Brown et al., 2005). With the increase of job satisfaction in business, organizational commitment increases (Testa, 2001). Jermier and Berkes (1979), Gomes (2009) and Kappagoda (2012) also indicated in their studies that organizational commitment affects job satisfaction positively. Accordingly, the hypotheses and research model of the study was developed as stated below:

$H_{1}$ : Ethical leadership positively affects job satisfaction.
$\mathrm{H}_{2}$ : Ethical leadership positively affects organizational commitment.

$\mathrm{H}_{3}$ : Organizational commitment positively affects job satisfaction.

$\mathrm{H}_{4}$ : Organizational commitment has a mediator role in the relationship of ethical leadership and job satisfaction.

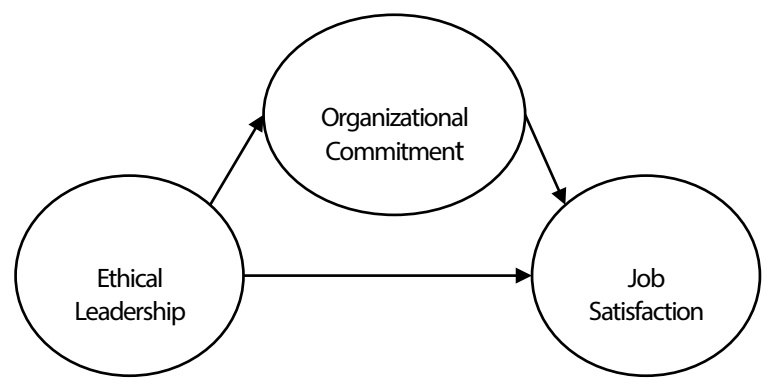

Figure 1: Research Model

\section{METHODOLOGY}

\subsection{Instrument}

A survey research technique was used as the quantitative research method. The survey questionnaire in the study is composed of four sections. In the first section, there are 10 statements used for measuring ethical leadership behaviors, 7 statements for measuring the organizational commitment of employees are in second section and 3 statements for measuring job satisfaction of employees are in the third section. The questionnaire benefitted from the studies of Brown et al. (2005) for leadership behavior scale, Mowday et al. (1979) for the one-dimensional scale for organizational commitment and Brayfield and Rothe (1951) and Barsky et al. (2004) for job satisfaction scale. One of the job satisfaction statements was measured with reverse coding to ensure control. In the fourth section, there are seven questions regarding demographic information about employees.

\subsection{Data Collection and Sample}

The population of the study was composed of employees working in four and five star hotels in the Antalya region in Turkey. The questionnaires prepared with this scope were conducted by pollsters and applied to employees of four and five star hotels in the centre of the Antalya, Alanya and Manavgat region. 500 questionnaires were delivered in total and 400 copies of them returned. After removing those questionnaires with incomplete information, 391 questionnaires were used for analysis.

The majority of participants were composed of men $(62.7 \%)$. When the ages of participants were analyzed, it was seen that the highest portion were in the $26-33$ age range. Also, $62 \%$ of participants were single. When the educational background of 
participants was analyzed, it was seen that the majority held high school diplomas (45.8\%) and had a primary school (22.3\%) education. When the occupational background of employees was examined, it was found that of the majority from five star hotels (79\%), 29.9\% has been working less than 1 year and $32.5 \%$ were working in catering departments.

\subsection{Data Analysis}

In accordance with the scope of the current study, structural equation modeling was used in order to determine the relationship between leadership, organizational commitment and job satisfaction. The two step approach, recommended by Anderson and Gerbing (1988), is preferred in structural equation modeling. Therefore, the measurement model was tested first followed by the structural model. Since the likelihood procedure method was used in estimation of the measurement model and structural model, normal distribution presumption was checked. For that reason, skewness and kurtosis values were analyzed. It can be stated that normal distribution was not disturbed since the skewness and kurtosis values did not exceed the proposed value (Kline, 2011).

In determining the mediator role of organizational commitment between leadership and job satisfaction, which is the other scope of the study, the B-K method (Baron and Kenny, 1986) was preferred.

\section{RESULTS}

\subsection{Measurement Model}

Since, following the results of the measurement model, the standard factor loadings regarding the first statement of organizational commitment and second statement of job satisfaction were under the recommended value .50, these two statements were removed and the model was re-estimated. Results regarding the measurement model are as shown in Table 1.

Table 1: Measurement Model Results

\begin{tabular}{|c|c|c|c|c|c|c|c|}
\hline Dimensions & Observed Variables & $\begin{array}{l}\text { Std. Fac. } \\
\text { Load. }\end{array}$ & $\begin{array}{c}\mathrm{t} \\
\text { values }\end{array}$ & $\begin{array}{l}\text { Construct } \\
\text { Reliability }\end{array}$ & AVE & \multicolumn{2}{|l|}{ Correlation } \\
\hline \multirow{10}{*}{ 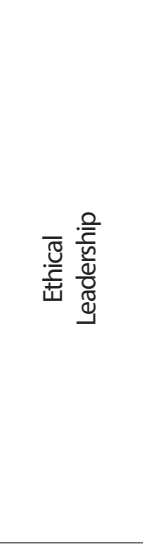 } & My manager conducts his/her personal life in an ethical manner. & .77 & *Fixed & \multirow{10}{*}{.94} & \multirow{10}{*}{.59} & $\begin{array}{l}\text { Organizational } \\
\text { Commitment }\end{array}$ & .79 \\
\hline & $\begin{array}{l}\text { My manager defines success not just by results but also the way } \\
\text { that they are obtained. }\end{array}$ & .77 & 16.14 & & & $\begin{array}{l}\text { Job } \\
\text { Satisfaction }\end{array}$ & .81 \\
\hline & My manager listens to what employees have to say. & .82 & 17.57 & & & & \\
\hline & My manager disciplines employees who violate ethical standards. & 79 & 16.83 & & & & \\
\hline & My manager makes fair and balanced decisions. & .83 & 17.72 & & & & \\
\hline & $\begin{array}{l}\text { When making decisions, my manager asks "what is the right thing } \\
\text { to do?" }\end{array}$ & .67 & 13.67 & & & & \\
\hline & My manager can be trusted. & .74 & 15.43 & & & & \\
\hline & Discusses business ethics or values with employees & .74 & 15.35 & & & & \\
\hline & $\begin{array}{l}\text { My managersets an example of how to do things the right way in } \\
\text { terms of ethics. }\end{array}$ & .79 & 16.64 & & & & \\
\hline & My manager has the best interests of employees in mind. & .76 & 15.93 & & & & \\
\hline \multirow{6}{*}{ 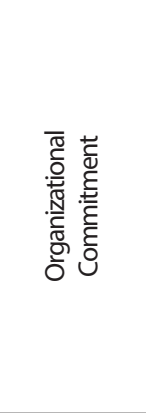 } & $\begin{array}{l}\text { I talk up this organization to myfriends as a great organization to } \\
\text { work for. }\end{array}$ & .80 & *Fixed & \multirow{6}{*}{.92} & \multirow{6}{*}{.65} & $\begin{array}{l}\text { Job } \\
\text { Satisfaction }\end{array}$ & .90 \\
\hline & $\begin{array}{l}\text { I would acceptal most any type of job assignment in order to } \\
\text { keep working for this organization. }\end{array}$ & .76 & 16.62 & & & & \\
\hline & I find that my values and the organization's values are very similar. & .80 & 17.74 & & & & \\
\hline & I am proud to tell others that I am part of this organization. & .85 & 19.31 & & & & \\
\hline & $\begin{array}{l}\text { This organization really inspires the very best in me in the way of } \\
\text { job performance. }\end{array}$ & .82 & 18.48 & & & & \\
\hline & $\begin{array}{l}\text { For me this is the best of all possible organizations for which to } \\
\text { work. }\end{array}$ & .81 & 17.92 & & & & \\
\hline \multirow{2}{*}{ 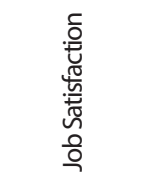 } & I am satisfiedwithmyjob at allpoints. & .82 & ${ }^{*}$ Fixed & \multirow[b]{2}{*}{.82} & \multirow[b]{2}{*}{.70} & & \\
\hline & I like working here in general sense. & .85 & 18.67 & & & & \\
\hline $\begin{array}{l}\text { Goodness- } \\
\text { of-fit } \\
\text { statistics }\end{array}$ & \multicolumn{7}{|l|}{$\chi^{2}=415.99, \mathrm{df}=132, \chi^{2} / \mathrm{df}=3.151, \mathrm{RMSEA}=.074, \mathrm{CFI}=.98, \mathrm{NFI}=.98, \mathrm{IFI}=.98$} \\
\hline
\end{tabular}


When the Table 1 is analyzed, it can be stated that goodness-of-fit-statistics is at an acceptable level (Marsh and Hocevar, 1985; Schermelleh-Engel, Moosbrugger and Müller, 2003). Addition to fit indices regarding the measurement model, information regarding the discriminant validity, construct reliability and convergent validity used for the check of construct validity are shown in Table 1 . When the Table 1 is analyzed, it is seen that all standard factor loadings are bigger than the recommended .50 value and all AVE values are in excess of the .50 value. Accordingly, it can be stated that convergent validity was provided (Hair et al., 2009). Also, the discriminant validity was insured, since the correlation values between structures exceeded the .90 value (Kline, 2011). Lastly, composite construct reliability (CCR) was checked while the construct reliability was being evaluated. As seen in Table 1, CCR values are .94 for leadership, .92 for organizational commitment and .80 for job satisfaction. According to findings, construct reliability was insured (Fornell and Larcker, 1981). Thus, it can be stated that construct validity was insured in addition to fit indices.

\subsection{Structural Model}

After developing the measurement model, the structural model was developed in order to test the hypotheses. The results regarding the structural model are shown in Table 2.

Table 2: Results of SEM and Hypotheses

\begin{tabular}{|l|c|c|c|}
\hline \multicolumn{1}{|c|}{ Hypotheses } & Std. Fac. Load. $\lambda$ & t values & Result \\
\hline $\begin{array}{l}\mathrm{H}_{1}: \text { Ethical Leadership } \rightarrow \\
\text { Organizational Commitment }\end{array}$ & .79 & 21.12 & Supported \\
\hline $\begin{array}{l}\mathrm{H}_{2}: \text { Ethical Leadership } \rightarrow \\
\text { Job Satisfaction }\end{array}$ & .24 & 3.85 & Supported \\
\hline $\begin{array}{l}\mathrm{H}_{3}: \text { Organizational } \\
\text { Commitment } \rightarrow \\
\text { Job Satisfaction }\end{array}$ & .72 & 11.17 & Supported \\
\hline $\begin{array}{l}\mathrm{R}^{2}: \text { Organizational Commit- } \\
\text { ment }=.62, \\
\text { Job Satisfaction }=.85\end{array}$ & & & \\
\hline $\begin{array}{l}\text { Goodness-of-fit } \\
\text { statistics }\end{array}$ & $\begin{array}{l}\chi^{2}=485.07, \mathrm{df}=147, \chi^{2} / \mathrm{df}=3.299 \mathrm{RMSEA}=.077 \\
\mathrm{CFI}=.98, \mathrm{NFI}=.97, \mathrm{FFI}=.98 .\end{array}$ \\
\hline
\end{tabular}

When the Table 2 was analyzed, it was seen that fit indices regarding the structural model are at an acceptable level $\left(\mathrm{X}^{2} / \mathrm{df}=3.299\right.$, $\mathrm{RMSEA}=.077 \mathrm{CFI}=.98$, $\mathrm{NFI}=.97, \mathrm{IFl}=.98$ ) (Marsh and Hocevar, 1985; Schermelleh-Engel et al., 2003). Tt was found that ethical leadership has a positive effect on organizational commitment $(\beta=.79, \mathrm{t}=21.12)$ and job satisfaction $(\beta=.24, t=3.85$, while organizational commitment has a positive effect on just job satisfaction $(\beta=.72, t=$ 11.17). Therefore $H_{1}, H_{2}$ and $H_{3}$ were supported.

\subsection{Mediation Analysis}

Measuring the mediator roles of intervening variables in structural models is important for a developed model (Baron and Kenny, 1986). Therefore, the mediator role of organizational commitment between ethical leadership and job satisfaction was examined in this study.

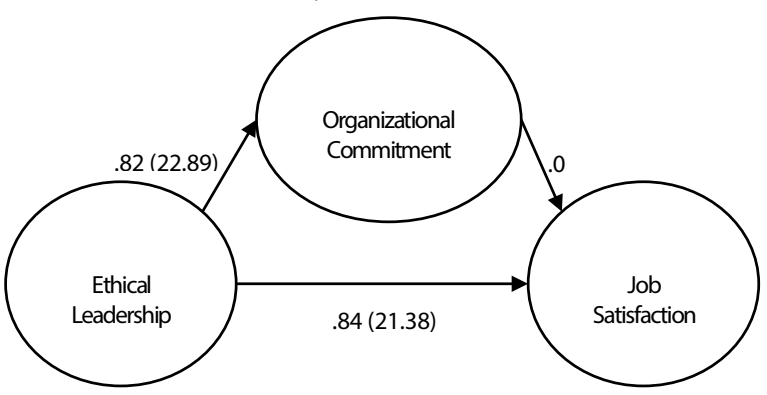

Figure 2: Constrained Model

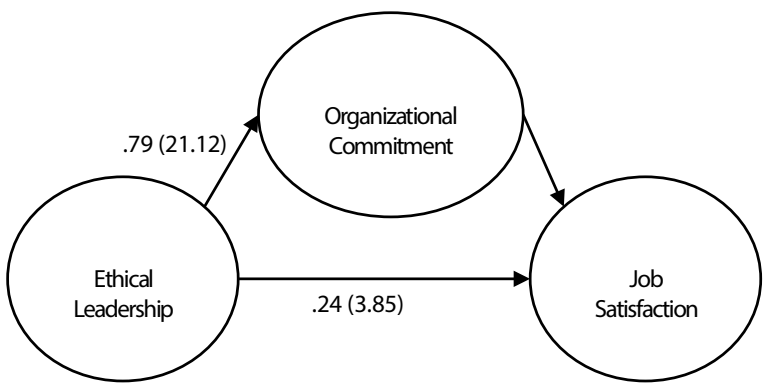

Figure 3: Mediating Model

The B-K method was preferred in determining the mediator role of organizational commitment. As seen in measurement and structural models, the first three conditions of B-K were provided. Because of this, the fourth condition was examined. Therefore, the constrained model, with which the effect of leadership on job satisfaction was measured, was developed first (Figure 2). According to this model, the effect of leadership on job satisfaction was found significant $(\beta=.84, t=21.38)$. Following this, the mediating model by which the hypotheses were also tested was developed (Figure 3). According to this model, the effect of leadership on job satisfaction was found significant $(\beta=.24, t=3.85)$, but its effect was decreased. Accordingly, it can be stated that organizational commitment has a partial mediator effect between ethical leadership and job satisfaction.

In order to understand which model is better, the mediating model $\left(x^{2}=485.07, d f=147, p<.001\right)$ and constrained model $\left(X^{2}=578.78, d f=148, p<.001\right)$ was compared. For this comparison, the chi-square difference test was used. According to the results of the chi-square difference test, it can be stated that the mediating model is better $\left(\Delta \mathrm{X}^{2}=93.71, \Delta \mathrm{df}=1\right.$, 
$\mathrm{p}<.001$ ), and so the mediator role of organizational commitment is significant. Therefore, $\mathrm{H}_{4}$ was partially supported.

\section{CONCLUSION AND DISCUSSION}

As mentioned earlier, much research has been conducted in order to explain the relationship between leadership studies and job satisfaction and organizational commitment and it has been found that there is a significant relationship between leadership, job satisfaction and organizational commitment. Raja (2011), Rehman et al.(2012), Bučiūnienè and Škudienè (2008), Lagomarsino and Cordona (2003) and Lo, Ramayah and Min (2009) showed in their studies that there is a positive relationship between transactional leadership and transformational leadership and organizational commitment and job satisfaction, while Randere and Chaudhry (2012) stated that there is a positive relationship between consultative and participative leadership and employee commitment and job satisfaction. Bučiūnienè and Škudienè (2008) as well stated that there is a negative relationship between laissez-faire leadership and organizational commitment. However, there is little research that shows the relationship between ethical leadership and organizational commitment and job satisfaction, especially in terms of accommodation businesses. In this study in which the relationship between ethical leadership and organizational commitment and job satisfaction were examined, it was found that ethical leadership has a positive influence on organizational commitment and job satisfaction. Our results support the results of Ponnu and Tennakoon (2009), Brown et al. (2005), Lim (2012), Toor and Ofori (2009) Ghahroodi et al. (2013) and Zhu et al. (2004). In the research, it was determined that organizational commitment has a positive influence on job satisfaction. This result supports Jermier and Berkes (1979), Gomes (2009), Kappagoda (2012) in their studies. But there is much study in the literature showing that job satisfaction influences organizational commitment positively (Lumley et al., 2011; Lok and Crawford, 1999; Salami, 2008; Azeem, 2010; Günlü, Aksaraylı and Perçin, 2010). It was seen in the analysis results that organizational commitment has a mediator role between ethical leadership and job satisfaction. In other words, the effect of ethical leadership on job satisfaction is quite small, whereas it becomes more effective when organizational commitment and ethical leaderships are integrated. In this regard, it can be stated that leaders who act ethically make employees more satisfied with their jobs by enhancing organizational commitment. While studies that show organizational commitment's mediating role between ethical leadership and job satisfaction could not be found in the literature, there have been other studies (Trang et al., 2013; Clugston, 2000; Gomes, 2009) conducted on organizational commitment's mediating role for other variables (work motivation, leadership style, learning organization, employees performance, job satisfaction and organizational change). Consequently, $\mathrm{H1} 1, \mathrm{H} 2, \mathrm{H} 3$ and $\mathrm{H} 4$ hypothesis are supported.

When the research results were analyzed, the fact that ethical leadership has an influence on job satisfaction and organizational commitment was seen both in the research results and the literature. This situation should be taken into consideration, especially in the hotel industry. Business managers and owners can enhance organizational commitment by acting ethically and can influence job satisfaction in an environment positive organizational commitment. In this way, managers can decrease worker rate of turnover, which is a chronic problem in the tourism sector. The ethical problems seen in the tourism sector (overtime, having no job security, wage problems, cheating tourists, broken promises, etc.) can be minimized if managers act ethically and impose ethical behaviors on employees.

This study was carried out in four and five-star hotels in the Antalya province in Turkey with the help of the questionnaire method. The main reason why the study is not comprehensive was limited time and budget. However, considering the deficiency in the literature, the relationship between ethical leadership and different regions, different tourism managements with different perspectives on subjects, especially organization culture, organizational trust, strategic decision making, organizational inertia, etc. should be further investigated. Also, transnational comparisons could contribute to the ethical leadership literature. In addition, researchers could research ethical leadership using qualitative study methods, as well as quantitative study methods.

Today, acting ethically, transparency and accountability have become more important for businesses; therefore, researchers should examine the effect of ethical leadership on business by carrying out quantitative and qualitative research regarding this point. Taking into consideration the deficiencies in literature, topics such as ethical leadership, organizational culture, spirit, confidence, strategic decision-making, game theory and organizational inertia could be investigated in different places and businesses. As well, the role of social culture in perceiving ethical leadership could be examined by making comparisons between societies 


\section{REFERENCES}

Acar, G., Kaya, M. ve Şahin, M.Y. (2012) "School Administrators Ethical Leadership Behavior Effects on Physical Education Teachers Organizational Justice Level" Turkish Journal of Sport and Exersice, 14 (3):51-58.

Adeyemi, T.O. (2010) 'Principals' Leadership Styles and Teachers' Job Performance in Senior Secondary Schools in Ondo" Journal of Education Administration and Policy Studies,2(6):83-91.

Ahmadi, S.A.A., Ahmadi, F. ve Zohrabi, M. (2012) "Effect of the Leadership Styles on the Organizational Commitment Given the Staff Personality Traits" Interdisciplinary Journal of Contemporary Research In Business, 4(1):247-264.

Ahmed, B., Shad, I., Mumtaz, R. ve Tanveer, Z. (2012) "Organizational Ethics and Job Satisfaction: Evidence from Pakistan" African Journal of Business Management, 6(8):2966-2973.

Aioanei, I. (2006) "Leadership in Romania" Journal of Organizational Change Management, 19 (6):705-712.

Anderson, J.C.ve Gerbing, D.W. (1988) "Structural Equation Modeling in Practice: A Review and Recommended Two-Step Approach" Psychological Bulletin, 103(3): 411-423.

Angle, H.L. ve Perry, J. L. (1981) "An Empirical Assessment of Organizational Commitment and Organizational Effectiveness" Administrative Science Quarterly, 26(1):1-14.

April, K., Peters, K., Locke, K. ve Mlambo, C. (2010) "Ethics and Leadership: Enablers and Stumbling Blocks" Journal of Public Affairs, 10:152-172.

Aronson, E. (2001) "Integrating Leadership Styles and Ethical Perspectives" Canadian Journal of Administrative Sciences, 18(4):244-256.

Atmojo, M. (2012) "The Influence of Transformational Leadership on Job Satisfaction, Organizational Commitment, and Employee Performance" International Research Journal of Business Studies, 5(2):113-128.

Azeem, S.M. (2010) "Job Satisfaction and Organizational Commitment among Employees in the Sultanate of Oman" Psychology, 1(4):295-300.

Aziri, B. (2011) "Job Satisfaction: A Literature Review" Management Research and Practice, 3(4):77-86.

Baron, R.M. ve Kenny, D.A. (1986) “The ModeratorMediator Variable Distinction in Social Psychological Research: Conceptual, Strategic, and Statistical Considerations" Journal of Personality and Social Psychology, 51(6): 1173-1182.
Barsky, A., Thoresen, C.J., Warren, C.R., ve Kaplan, S.A. (2004) "Modeling Negative Affectivity and Job Stress: A Contingency-Based Approach" Journal of Organizational Behavior, 25:915-936.

Bass, B.M. (1990) Bass and Stogdill's Handbook of Leadership Theory, Research, and Managerial Applications, Third Edition, New York, The Free Press.

Bass, B.M. ve Steidlmeier, P. (1999) "Ethics, Character, and Authentic Transformational Leadership Behavior" The Leadership Quarterly, 10(2):181-217.

Brayfield, A.H. ve Rothe, H.F. (1951) "An Index of Job Satisfaction" Journal of Applied Psychology, 35(5): 307-311.

Brown, B.B. (2003) 'Employees' Organizational Commitment and Their Perception of Supervisors' Relations Oriented and Task-Oriented Leadership Behaviors" Unpublished Doctoral Dissertation, Virginia, Faculty of the Virginia Polytechnic Institute and State University.

Brown, M.E. ve Mitchell, M.S. (2010) "Ethical and Unethical Leadership: Exploring New Avenues for Future Research" Business Ethics Quarterly, 20(4):583-616.

Brown, M.E., Trevino, L.K. ve Harrison, D.A. (2005) "Ethical Leadership: A Social Learning Perspective for Construct Development and Testing" Organizational Behaviour and Human Decision Processes, 97:117-134.

Buchanan, B. (1974) "Building Organizational Commitment: The Socialization of Managers in Work Organizations" Administrative Science Quarterly, 533-546.

Bučiūnienè, I. ve Škudienè, V. (2008) "Impact of Leadership Styles on Employees' Organizational Commitment in Lithuanian Manufacturing Companies" South East European Journal of Economics and Business, 3(2):57-66.

Clugston, M. (2000) "The Mediating Effects of Multidimensional Commitment on Job Satisfaction and Intent to Leave" Journal of Organizational Behavior, 21(4):477-486.

Cohen, A. (1993) "Age and Tenure in Relation to Organizational Commitment: A meta-Analysis" Basic and Applied Social Psychology, 14(2):143-159.

Cohen, A. (2007) "Commitment Before and After: An Evaluation and Reconceptualization of Organizational Commitment" Human Resource Management Review, 17(3):336-354.

Çavuş, Ş. ve Gürdoğan, A. (2008) "Örgüt Kültürü ve Örgütsel Bağglılık İlişkisi: Beş Yıldızlı Otel İşletmesinde Araştırma" Ticaret ve Turizm Eğitim Fakültesi Dergisi, 1:18-34. 
Çelik, S. (2011) "Liderlik Tarzları İle Stratejik Kararlar Arasındaki İlişkisi: İstanbul'daki 4 ve 5 Yıldızlı Otel İşletmelerinde Bir Araştırma” Yayınlanmamış Yüksek Lisans Tezi, Düzce, Düzce Üniversitesi Sosyal Bilimler Enstitüsü.

Çokluk, Ö. ve Yılmaz, K. (2010) “The Relationship Between Leadership Behavior and Organizational Commitment in Turkish Primary Schools" Bilig-Journal of Turkish World Social Sciences, 14(54):75-92.

Darvish, H. ve Rezaei, F. (2004) “The Impact Of Authentic Leadership on Job Satisfaction and Team Commitment" Management and Marketing, 6(3):421-436.

Davis, K. (1981) Human Behavior at Work Organization Behavior, 6th Edition, New York. Mc Graw Hill.

DeConinck, J.B. (2010) "The Influence of Ethical Climate on Marketing Employees' Job Attitudes and Behaviors" Journal of Business Research, 63(4):384-391.

Den Hartog, D.N. ve Belschak, F.D. (2012) "Work Engagement and Machiavellianism in the Ethical Leadership Process" J.Business Ethics, 107:35-47.

Dercks, L. (2001) "The European Commission's Business Ethics: a Critique of Proposed Reforms" Business Ethics: a European Review, 10(4): 346-359.

Elçi, M., Şener İ., Aksoy, S. ve Alpkan, L. (2012) "The Impact of Ethical Leadership and Leadership Effectiveness on Employees' Turnover Intention: The Mediating Role of Work Related Stress" Procedia-Social and Behavioral Sciences, 58:289-297.

Fornell, C., ve Larcker, D. F. (1981) "Evaluating Structural Equation Models With Unobservable Variables and Measurement Error" Journal of Marketing Research, 18(1): 39-50.

Gardner, W.L., Avolio, B.J., Luthans, F. , May, D.R. ve Walumbwa, F. (2005) "Can You See the Real Me" A self-Based Model of Authentic Leader and Follower Development" The Leadership Quarterly, 16:343-372.

Ghahroodi, H.K., Mohd, M.Z. B.T.S., ve Ghorban, Z.S. (2013) "Examining Ethical Leadership and Its Impacts on the Followers' Behavioral Outcomes" Asian Social Science, 9(3):91.

Gomes, D.R. (2009) "Organizational Change and Job Satisfaction: The Mediating Role of Organizational Commitment" Exedra: Revista Cientifica, (1):177-195.

Günlü, E., Aksaraylı, M. ve Perçin N.S. (2010) "Job Satisfaction and Organizational Commitment of Hotel Managers in Turkey" International Journal of Contemporary Hospitality Management, 22(5):693-717.

Hair, J.F., Black, W.C., Babin, B.J. ve Anderson, R.E. (2009) Multivariate Data Analysis, 7th Edition, New York, Prentice Hall.
Hoppock, R. (1935) Job Satisfaction. New York, Harper and Brother.

Jaros, S.J. (1997) "An Assessment of Meyer and Allen's (1991) Three-Component Model of Organizational Commitment and Turnover İntentions" Journal of Vocational Behavior, 51(3):319-337.

Jermier, J. ve Berkes, L. (1979) "Leader Behavior in a Police Command Bureaucracy: A Closer Look at the Quasi-Military Model” Administrative Science Quarterly, 24:1-23.

Kalshoven, K., Den Hartog, D.D. ve De Hoog, A.H.B. (2011) "Ethical Leadership at Work Questionnaire (ELW): Development and Validation of a Multidimensional Measure" The Leadership Quarterly, 22:51-69.

Kappagoda, S. (2012) "Organizational Commitment: A Mediator of the Relationship Between Job Satisfaction and Job Performance in the Commercial Banks in Sri Lanka" Academicia: An International Multidisciplinary Research Journal, 2 (9):1-11.

Kim, H.J., Tavitiyaman P. ve Kim W.G. (2009) "The Effect of Management Commitment to Service on Employee Service Behaviors: The Mediating Role of Job Satisfaction" Journal of Hospitality and Tourism Research, 33(3):369-390.

Kimbel, R.D. (2002) “The Relationship Between Employee Sconstructive Thinking Ability and Organizational Commitment" Unpublished Doctoral Dissertation, Nova, Southeastern University.

Kline, R.B. (2011) Principles and Practice of Structural Equation Modeling, Third Edition, New York, The Guilford Press.

Lagomarsino, R. ve Cardona P. (2003) "Relationships among Leadership, Organizational Commitment and OCB in Uruguayan Health Institutions" IESE Business School, University of Navarra. WP No 494.

Lam, T., Zhang, H. ve Baum, T. (2001) "An Investigation of Employees' Job Satisfaction: the Case of Hotels in Hong Kong" Tourism Management, 22(2):157-165.

Lim, L.Y. (2012) "The Impact of Perceived Leadership and Ethical Leadership Behaviour on Job Satisfaction and Organisational Commitment" Unpublished Master Dissertation, Tunku Abdul Rahman Unıversıty, Faculty of Accountancy and Management.

Lo, M.C., Ramayah, T. ve Min, H.W. (2009) "Leadership Styles and Organizational Commitment: a Test on Malaysia Manufacturing İndustry" African Journal of Marketing Management, 1(6):133-139.

Locke, E.A. (1976) "The Nature and Cause of Job Satisfaction” Punnette, M.D. (ed.) Handbook of Individual and Organizational Psychology, Chicago, IL Rand McNally. 
Lok, P. ve Crawford, J. (1999) "The Relationship Between Commitment and Organizational Culture, Subculture, Leadership Style and Job Satisfaction in Organizational Change and Development" Leadership and Organization Development Journal, 20(7):365-374.

Lumley, E.J., Coetzee, M., Tladinyane, R. ve Ferreira, N. (2011) "Exploring the Job Satisfaction And Organisational Commitment of Employees in the Information Technology Environment" Southern African Business Review, 15(1):100-118.

Marsh, H.W. ve Hocevar, D. (1985) "Application of Confirmatory Factor Analysis to the Study of SelfConcept: First-and Higher-Order Factor Models and Their Invariance Across Groups" Psychological Bulletin, 97(3):562-582.

Martin, A. ve Roodt, G. (2008) "Perception of Organisational Commitment, Job Satisfaction and Turnover Intentions in A Post-Merger South African Tertiary Institution" SA Journal of Industrial Psychology, 34(1):23-31.

Mathieu, J.E. ve Zajac D.M. (1990) "A Review and Meta-Analysis of the Antecedents, Correlates, and Consequences of Organizational Commitment" Psychological Bulletin, 108(2): 171.

Maxwell, G. ve Steele, G. (2003) "Organizational Commitment: A Study of Managers in Hotels" International Journal of Contemporary Hospitality Management, 15(7): 362-369.

Meyer, J.P. ve Allen, N.J. (1997) Commitment in the Workplace: Theory, Research, and Application. Thousand Oaks, CA: Sage Publications.

Meyer, J.P. ve Allen, N.J. (1991) "A Three Component Conceptualization of Organizational Commitment" Human Resource Management Review, 1:61-89.

Mihelic, K.K., Lipicnik, B. ve Tkavcic, M. (2010) "Ethical Leadership" International Journal of Management and Information Systems, 14(5):31-42.

Morrow, P.C. (1983) "Concept Redundancy in Organizational Research: The Case of Work Commitment" Academy of Management Review, 8(3):486-500.

Mowday, R.T., Steers, R. ve Porter, L.W. (1979) “The Measurement of Organizational Commitment" Journal of Vocational Behavior, 14(2):224-247.

Munir, Y., Malik, M.E., Ehsan, M., Javaid, B., Arshad, A., Khalid, M. ve Nazir, S. (2013) "Empirical Investigation of Ethical Leadership, Job Turnover, Job Satisfaction, Organizational Commitment, and Organizational Citizenship Behavior" Far East Journal of Psychology and Business, 10(2):12-20.
Naqvi, S.A.H., Hashmi, M.A., Raza, S.A., Zeeshan, A. ve Shaikh, F.F. (2011) "Impact of Supportive Leadership and Organizational Learning Culture as a Moderator On The Relationship of Psychological Empowerment and Organizational Commitment" Australian Journal of Business and Management Research, 1(8):65-71.

Ponnu, C.H. ve Tennakoon, G. (2009) "The Association Between Ethical Leadership and Employee Outcomes-The Malaysian Case" Electronic Journal of Business Ethics and Organization Studies, 14(1):21-32.

Porter, L., Crampon, W. ve Smith, F. (1976) “Organizational Commitment and Managerial Turnover: A Longitudinal Study" Organizational Behaviour and Human Performance, 15(1):87-98.

Powers, A. (2006) "An Exploratory Study of The Impact of Leadership Behavior on Levels of News Convergence and Job Satisfaction"L. Küng(ed.), Leadership in the Media Industry, Sweden: ARK Tryckaren AB.

Raja, A.S. ve Palanichamy, P. (2011) "Leadership Styles and Its Impact on Organizational Commitment" Asia Pacific Business Review, 7(3):167-175.

Randeree, K. ve Chaudhry, A.G. (2012) "Leadership-Style, Satisfaction and Commitment: An Exploration in The United Arab Emirates' Construction Sector. Engineering" Construction and Architectural Management, 19(1):61-85.

Rehman, S.U., Shareef, A., Mahmood, A. ve Ishaque, A. (2012) "Perceived Leadership Styles and Organizational Commitment" Interdiciplinary Journal of Contemporary Research in Business, 4(1):616-626.

Resick, C.J., Hanges, P.J., Dickson, M.W. ve Mitchelson, J.K. (2006) "A Cross-Cultural Examination of the Endorsement of Ethical Leadership" Journal of Business Ethics, 63:345-359.

Resick, C.J., Martin, G.S., Keating, M.A., Dickson, M.W., Kwan, H.K. ve Peng, C. (2011) "What Ethical Leadership Means to Me: Asian, American and European Perspectives" Journal of Business Ethics, 101:435-457.

Rızaoğlu, B. ve Ayyıldız, T. (2008) "Konaklama İşletmelerinde Örgüt Kültürü ve İş Tatmini: Didim Örneği” Anatolia: Turizm Araştırmaları Dergisi, 19(1):720.

Saari, L.M. ve Judge, T.A. (2004) "Employee Attitudes and Job Satisfaction" Human Resource Management, 43(4):395-407.

Salami, S.O. (2008) "Demographic and Psychological Factors Predicting Organizational Commitment Among Industrial Workers" Anthropologist, 10(1):31-38. 
Schermelleh-Engel, K., Moosbrugger, H. ve Müller, H. (2003) "Evaluating the Fit Structural Equation Models: Tests Of Significance and Descriptive Goodness-ofFit Measures" Methods of Psychological Research Online, $8(2): 23-74$

Schwepker, Jr, C.H. (2001) "Ethical Climate's Relationship to Job Satisfaction, Organizational Commitment, and Turnover Intention in the Salesforce" Journal of Business Research, 54(1):39-52.

$\mathrm{Su}$, H.W., Lee, L.T. ve Fan, C.K. (2011) "Turnover Determinants of New Employees in International Hotels" Journal of Service Science and Management, 4:158-164.

Suki, N.M. ve Suki, N.M. (2011) "Job Satisfaction and Organizational Commitment: the Effect of Gender" International Journal of Psychology Research, 6(5):1-15.

Testa, M.R. (2001) "Organizational Commitment, Job Satisfaction, and Effort in The Service Environment" The Journal of Psychology, 135(2):226-236.

Thomas, T., Schermerhorn, J.R. ve Dienhart, J.W. (2004) "Strategic Leadership of Ethical Behavior in Business" The Academy of Management Executive, 18(2):56-66.

Toker, B. (2007) "Demografik Değişkenlerin İş Tatminine Etkileri: İzmir'deki Beş ve Dört Yıldızlı Otellere Yönelik Bir Uygulama” Doğuş Üniversitesi Dergisi, 8(1):92-107.

Toor, S. ve Ofori, G. (2009) "Ethical Leadership: Examining the Relationships With Full Range Leadership Model, Employee Outcomes, and Organizational Culture" Journal of Business Ethics, 90(4):533-547.

Trang, I., Armanu, Sudiro, A. ve Noermijati (2013) "Organizational Commitment as Mediation Variable Influence of Work Motivation, Leadership Style and Learning Organization to the Employees Performance" Journal of Business and Management, 7(2):12-25.

Treviño, L.K., Brown, M. ve Hartman, L.P. (2003) "A Qualitative Investigation of Perceived Executive Ethical Leadership: Perceptions From Inside and Outside the Executive Suite" Human Relations, 56(1):5-37.

Tsai, P.C.F., Yen, Y.F., Huang, L.C. ve Huang, I.C. (2007) “A Study on Motivating Employees' Learning Commitment in the Post-Downsizing Era: Job Satisfaction Perspective" Journal of World Business, 42(2):157169.

Ulrich, C., O'Donnell, P., Taylor, C., Farrar, A., Danis, M. ve Grady, C. (2007) "Ethical Climate, Ethics Stress, and the Job Satisfaction of Nurses and Social Workers in the United States" Social Science and Medicine, 65(8):1708-1719.
Üngüren, E., Cengiz, F. ve Algür, S. (2009) "İş Tatmini ve Örgütsel Çatışma Yönetimi Arasındaki İlişkinin Belirlenmesi: Konaklama İşletmeleri Üzerinde Bir Araştırma” Elektronik Sosyal Bilimler Dergisi, 8(27):36-56.

Üngüren, E., Doğan, H., Özmen, M. ve Tekin, Ö. A. (2010) "Otel Çalışanlarının Tükenmişlik ve İş Tatmin Düzeyleri İlişkisi” Yaşar Üniversitesi Dergisi, 17(5):29222937.

Van den Akker, L., Heres, L., Lasthuizen, K. ve Six, F. (2009) "Ethical Leadership and Trust: It's All About Meeting Expectations" International Journal of Leadership Studies, 5(2):102-22.

Van Saane, N., Sluiter, J.K., Verbeek, J.H.A. M. ve Frings Dresen, M.H.W. (2003) "Reliability and Validity of Instruments Measuring Job Satisfaction-A Systematic Review” Occupational Medicine, 53(3):191-200.

Vitell, S.J. ve Singhapakdi, A. (2008) "The Role of Ethics Institutionalization in Influencing Organizational Commitment, Job Satisfaction, and Esprit De Corps" Journal of Business Ethics, 81(2):343-353.

Watson, T. (2010) "Leader Ethics and Organizational Commitment" Mid-Atlantic Leadership Scholars Forum, 3(1):16-26.

Webb, K.S. (2011) "Emotional Intelligence and Worker Commitment: The Impact of Leaders' Behavior on Employee Commitment to Their Supervisor and the Organization" Advancement of Management and International Business Conference Proceedings.

Weiss, D.J., Dawis, R.V. ve England, G.W. (1967) "Manual for the Minnesota Satisfaction Questionnaire" Minnesota Studies in Vocational Rehabilitation.

Yew, L.T. (2008) "Job Satisfaction and Affective Commitment: A Study of Employees in The Tourism Industry in Sarawak, Malaysia. World Review of Entrepreneurship" Management and Sustainable Development, $4(1): 85-101$.

Yukl, G. (2002) Leadership in Organizations, Fifth Edition, New-Jersey, PrenticeHall.

Zhu, W., May, D.R. ve Avolio, B.J. (2004) "The Impact of Ethical Leadership Behavior on Employee Outcomes: The Roles of Psychological Empowerment and Authenticity" Journal of Leadership and Organizational Studies, 11(1):16-26. 
